\title{
Erysipelothrix inopinata sp. nov., isolated in the course of sterile filtration of vegetable peptone broth, and description of Erysipelotrichaceae fam. nov.
}

\author{
Susanne Verbarg, ${ }^{1}$ Holger Rheims, ${ }^{2}$ Sabine Emus, ${ }^{2}$ Anja Frühling, ${ }^{1}$ \\ Reiner M. Kroppenstedt, ${ }^{1}$ Erko Stackebrandt ${ }^{1}$ and Peter Schumann ${ }^{1}$ \\ ${ }^{1} \mathrm{DSMZ}$ - Deutsche Sammlung von Mikroorganismen und Zellkulturen $\mathrm{GmbH}$, Mascheroder \\ Weg 1b, 38124 Braunschweig, Germany \\ ${ }^{2}$ Bayer Healthcare AG, Bayerwerk, 51368 Leverkusen, Germany
}

Correspondence

Erko Stackebrandt erko@dsmz.de
The genus Erysipelothrix contains two species with validly published names, Erysipelothrix rhusiopathiae (Migula, 1900; Skerman et al., 1980) and Erysipelothrix tonsillarum (Takahashi et al., 1987). Whilst the former species is the causative agent of swine erysipelas and a pathogen for other animals and humans (Wood \& Shuman, 1975), strains of the latter species are avirulent and have been isolated from the tonsils of apparently healthy pigs. E. rhusiopathiae was classified among the regular, non-spore-forming, Gram-positive rods (Jones, 1986) before its phylogenetic position within the radiation of the clostridia as a deeply branching lineage adjacent to members of cluster XVI (Eubacterium biforme, Streptococcus pleomorphus and Clostridium innocuum) was determined (Collins et al., 1994).

\section{Isolation}

In the course of validation of production processes in aseptic manufacturing of pharmaceuticals, a vegetablebased growth medium was tested for dilution performance. In the course of preparation of the vegetable CSB medium (peptone vegetable, $20.0 \mathrm{~g}$; (+)-D-glucose, $2.5 \mathrm{~g} ; \mathrm{K}_{2} \mathrm{HPO}_{4}$, $2.5 \mathrm{~g}$; water, $1000 \mathrm{ml}$ ), the water used for dilution was

The GenBank/EMBL/DDBJ accession number for the 16S rRNA gene sequence of Erysipelothrix inopinata MF-EP02 ${ }^{\top}$ is AJ550617.

A table showing fatty acid compositions is available as supplementary material in IJSEM Online. heated to $80{ }^{\circ} \mathrm{C}$ for $1 \mathrm{~h}$ and allowed to cool to room temperature. Dehydrated medium was then added to the water and the solution was filtered through a membrane filter (pore width, $0.2 \mu \mathrm{m}$ ). Following incubation of a medium sample at room temperature for 3 days, the medium became turbid. Microscopic analysis and plating in TSA (tryptic soy agar: casein peptone, $15 \mathrm{~g}$; soy peptone, $5 \mathrm{~g} ; \mathrm{NaCl}, 5 \cdot 0 \mathrm{~g}$; agar, $15 \cdot 0 \mathrm{~g}$; water, $1000 \mathrm{ml} ; \mathrm{pH} \mathrm{7 \cdot 3)}$ and TSS (TSA $+5 \%$ sheep blood) media indicated the presence of a single contaminant, strain MF-EP02 ${ }^{\mathrm{T}}$.

\section{Phylogenetic analyses}

Sequencing methods and analyses of phylogenetic relatedness followed described procedures (Rainey et al., 1996). The almost-complete sequence (1424 nt) of strain MF$\mathrm{EP} 02^{\mathrm{T}}$ was aligned to the ARB database of $16 \mathrm{~S}$ rRNA gene sequences (Ludwig et al., 2003) and subsequently to the DSMZ database of Gram-positive bacteria. The new isolate showed moderate sequence similarity to members of the genus Erysipelothrix (96.4\%) and lower similarity (91\%) to Holdemania filiformis (Willems et al., 1997), a species of Clostridium cluster XVI as defined by Collins et al. (1994). The 16S rRNA gene sequences of E. rhusiopathiae strains ATCC $19414^{\mathrm{T}}$ ( = DSM 5055 ${ }^{\mathrm{T}}$ ) and DSM 5056 were identical and were highly similar to the sequence of E. tonsillarum ATCC $43339^{\mathrm{T}}(99 \cdot 8 \%$ similarity). The gene sequence of strain MF-EP02 ${ }^{\mathrm{T}}$ is $99 \cdot 9 \%$ similar to that of strain Pecs 56 


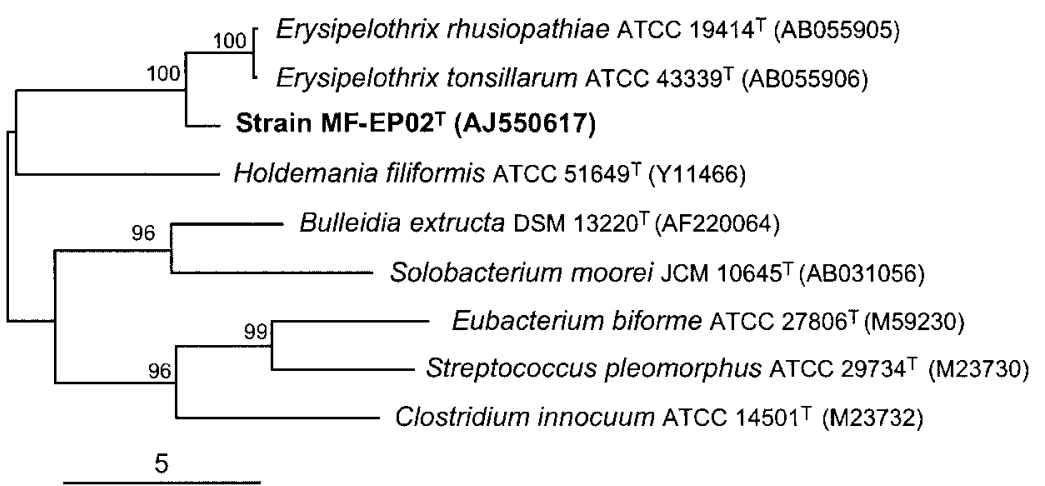

Fig. 1. 16S rRNA gene sequence dendro-
gram (DeSoete, 1983), displaying the phylo-
genetic position of strain MF-EPO $2^{\top}$ among
some phylogenetic neighbours. Numbers
indicate percentage of 1000 bootstrap
resamplings. GenBank accession numbers
of $16 \mathrm{~S}$ rRNA gene sequences are shown in
parentheses. Bar, $5 \%$ sequence divergence.

(AB055907), which is listed as 'unpublished' in GenBank/ EMBL. The 16S rRNA gene sequences of E. rhusiopathiae strains of serotypes 13 (AB019249) and 18 (AB019250) (Takeshi et al., 1999), which cover only the $3^{\prime}$ half of the molecule (about $790 \mathrm{nt}$ ), share $97 \cdot 5$ and $97 \cdot 8 \%$ similarity, respectively, with the corresponding fragment of strain MF-EP $02^{\mathrm{T}}$. Similarity values obtained for almost-complete sequences were transformed into phylogenetic distance values that compensated for multiple substitutions at any given site in the sequence (Jukes \& Cantor, 1969). A distance matrix dendrogram (DeSoete, 1983), which contains the GenBank accession numbers of reference strains used in the phylogenetic analysis, indicates that the phylogenetic position of strain MF-EP02 ${ }^{\mathrm{T}}$ lies adjacent to Erysipelothrix species (Fig. 1). Most of the less deeply branching points are supported by bootstrap values of $>95 \%$ (Felsenstein, 1993).

Based on moderate sequence similarity of $<97.5 \%$, the novel isolate can be considered as a taxonomic entity that is separate from the two species of Erysipelothrix with validly published names (Stackebrandt \& Goebel, 1994).

In silico analysis of the 16S rRNA gene sequence of strain MF-EP02 ${ }^{\mathrm{T}}$ for target sites for a primer pair that was designed to identify members of the genus Erysipelothrix (Makino et al., 1994) indicates that these primers would also identify strain MF-EP02 ${ }^{\mathrm{T}}$.

\section{RiboPrint analysis}

Automated ribotyping was carried out with the RiboPrinter microbial characterization system (Qualicon; DuPont). Sample preparation and analysis were performed according to the manufacturer's instructions; EcoRI was used to generate restriction fragments. The RiboPrint pattern of strain MF-EP02 ${ }^{\mathrm{T}}$ confirmed the differentiation of this strain from the two Erysipelothrix species (Fig. 2).

\section{Chemotaxonomic analyses}

In order to circumscribe the novel Gram-positive isolate, chemical properties of taxonomic relevance for members of the Clostridium subphylum were analysed. Cells for menaquinone analysis were obtained from biomass that was grown under aerobic and anaerobic conditions on TSB agar $+5 \%$ sheep blood. Isoprenoid quinones were extracted by chloroform/methanol $(2: 1, \mathrm{v} / \mathrm{v})$ from lyophilized cells, purified by preparative TLC on silica gel and analysed by HPLC (Collins et al., 1977; Groth et al., 1996). None of the Erysipelothrix strains, including isolate MF-EP02 ${ }^{\mathrm{T}}$, contained significant amounts of menaquinones, no matter what conditions cells were grown under for the preparation of isoprenoid quinones. Traces of MK-7 were detected in cells of E. tonsillarum DSM $14972^{\mathrm{T}}$ following aerobic cultivation. The lack of significant amounts of menaquinones in strains of E. rhusiopathiae confirms the results of Collins \& Jones (1981).

Fatty acid methyl esters were prepared from $40-80 \mathrm{mg}$ wet cells (Miller, 1982) that were grown on TSBA/blood agar and columbia agar. Extracts of the methanolysates were analysed by the MIDI microbial identification system as described by Sasser (1990). The fatty acid composition of strain MF-EP02 ${ }^{\mathrm{T}}$ reveals similarity to those of strains of Erysipelothrix species (see Supplementary Table in IJSEM Online). A dendrogram of fatty acid methyl ester relationships is depicted in Fig. 3. The pattern is dominated by $\mathrm{C}_{18: 1} 9$ cis $(>30 \%), \mathrm{C}_{16: 0}(>24 \%)$ and $\mathrm{C}_{18: 0}(>10 \%)$ fatty acid methyl esters; quantitative values for strain MF$\mathrm{EP} 02^{\mathrm{T}}$ are given in the species description. This pattern differs from that of $H$. filiformis ATCC $51649^{\mathrm{T}}$, which contains higher amounts of $\mathrm{C}_{18: 1} 9$ cis $(50 \%)$, additional minor components and significant amounts of dimethyl acetal $\left[\mathrm{C}_{18: 1} 9\right.$ cis $(12 \%)$ and $\left.\mathrm{C}_{16: 0}(4 \%)\right]$ (Willems et al., 1997).

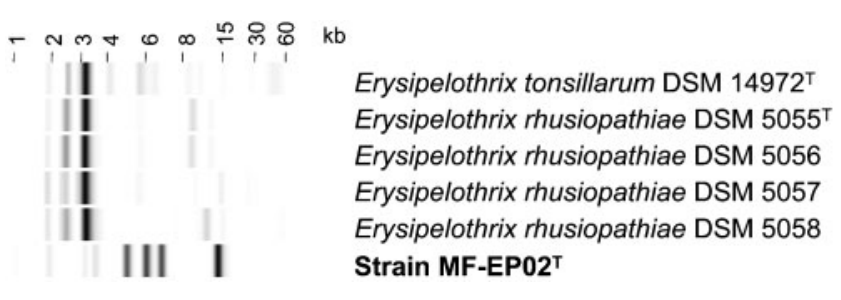

Fig. 2. Diversity of normalized EcoRI ribotype patterns found for members of the genus Erysipelothrix and strain MF-EPO2 ${ }^{\top}$. 


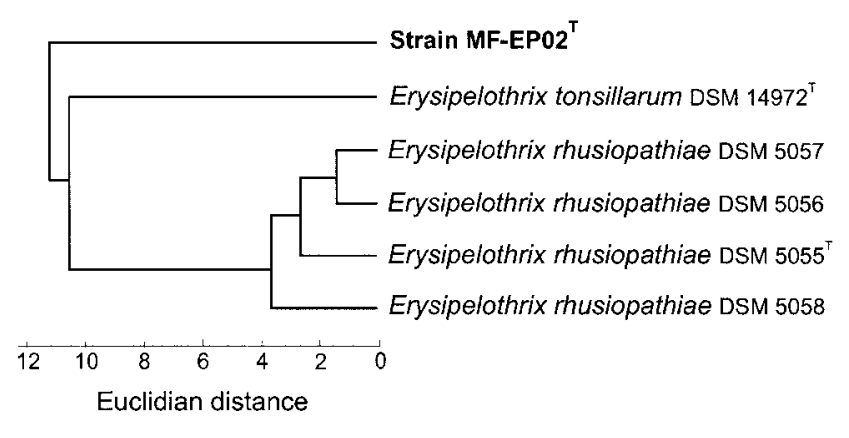

Fig. 3. Dendrogram of relationships based on Euclidian distances between fatty acid methyl ester patterns.

Analysis of the peptidoglycan structure followed the method described by Schleifer \& Kandler (1972), modified as described by Willems et al. (1997). Two-dimensional TLC of the partial acid hydrolysate of strain MF-EP02 ${ }^{\mathrm{T}}$ revealed, besides the presence of lysine, glutamic acid, glycine, serine, alanine, muramic acid and glucosamine, the presence of, besides others, the fragments $D-G l u \rightarrow G l y$, L-Ser $\rightarrow$ D-Glu and L-Lys $\rightarrow$ L-Lys, whereas aspartic acid or fragments that contained aspartic acid were missing. The quantitative amino acid composition (MacKenzie, 1987) is Ala : Gly: Ser: Glu : Lys $=1 \cdot 7: 0 \cdot 7: 0 \cdot 9: 1 \cdot 0: 1 \cdot 5$. It can thus be deduced that the peptidoglycan type is $\mathrm{B} 1 \delta$, with the interpeptide bridge being Gly $\rightarrow$ L-Lys $\rightarrow$ L-Lys, which is identical to that reported for E. rhusiopathiae (Schubert \& Fiedler, 2001) but different from that reported for H. filiformis ATCC $51649^{\mathrm{T}}$, in which the interpeptide bridge consists of L-Asp $\rightarrow$ L-Lys.

The DNA G $+\mathrm{C}$ content of strain MF-EP02 ${ }^{\mathrm{T}}$ was determined by HPLC (Mesbah et al., 1989) to be $37 \cdot 4 \mathrm{~mol} \%$, which corresponds to the range of $\mathrm{G}+\mathrm{C}$ contents found in members of the genus Erysipelothrix (Takahashi et al., 1992).

\section{Physiological properties}

Utilization of substrates and enzyme activities of strain MF-EP02 ${ }^{\mathrm{T}}$ and strains of Erysipelothrix species were done with the Biolog GP and API STREPT microtitre plate panels, respectively. Catalase and oxidase tests followed the description of Smibert \& Krieg (1994). Although many test reactions were identical for these strains, isolate MF$\mathrm{EP} 02^{\mathrm{T}}$ differed in a significant number of tests from both Erysipelothrix species with validly published names, which confirms its phenotypic uniqueness (Table 1).

\section{Taxonomic conclusions}

16S rRNA gene sequence analysis indicates a close phylogenetic relationship of strain MF-EP $02^{\mathrm{T}}$ to members of the genus Erysipelothrix. Phylogenetic position per se, however, is not a reliable indication of genus affiliation, as similarity values change with each novel species that is added to the genus. The hallmark of Erysipelothrix is the presence of a type B cell wall, in which the peptide bridge is formed between amino acids at positions 2 and 4 of adjacent peptide side-chains and not, as in the vast majority of bacteria, between amino acids at positions 3 and 4 . In order to link the two carboxylic groups of amino acids at positions 2 and 4, the interpeptide bridge of $B$ types must contain at least one diamino acid residue. The $B$ type occurs within the family Microbacteriaceae, order Actinomycetales, and in some members of the Clostridium subphylum, e.g. Erysipelothrix, Holdemania, Acetobacterium, Clostridium barkeri and Eubacterium limosum (Schleifer \& Kandler, 1972; Willems et al., 1997). Strain MF-EP02 ${ }^{\mathrm{T}}$ has exactly the same peptidoglycan amino acid composition as that reported previously for E. rhusiopathiae and that found for E. tonsillarum in this study, which is different from that of the nearest (although remote) neighbour, Holdemania filiformis (Willems et al., 1997). Although the type strains of E. rhusiopathiae and E. tonsillarum (Takahashi et al., 1987) share almost-identical 16S rRNA gene sequences (99.8\% similarity) and RiboPrint patterns (Fig. 2), their DNA-DNA reassociation values are only 18-36\%, which confirms their difference at the physiological level and, hence, their separate species status. Considering the distinct RiboPrint pattern of strain MFEP02 ${ }^{\mathrm{T}}$ and its moderate $16 \mathrm{~S}$ rRNA gene sequence similarities to type strains of the genus Erysipelothrix, we refrained from performing DNA-DNA reassociation studies.

The decision to propose strain MF-EP02 ${ }^{\mathrm{T}}$ as a member of a novel Erysipelothrix species has been made on the basis of its lack of menaquinone. Chemotaxonomic properties play a decisive role in the delineation of Gram-positive taxa and the absence of isoprenoid quinones under aerobic and anaerobic growth appears to be sufficiently significant to justify the affiliation of strain MF-EP02 ${ }^{\mathrm{T}}$ to the genus Erysipelothrix. Members of this genus form an individual line of descent within the phylogenetic confines of clostridia and bacilli, for which a novel family, Erysipelotrichaceae fam. nov., is proposed. This family, aside from its phylogenetic distinctiveness, is defined predominantly by its unique peptidoglycan type. As the novel family is isolated phylogenetically, a set of signature nucleotides that define the novel family is not indicated, but may be defined once neighbouring members have been described.

\section{Description of Erysipelotrichaceae fam. nov.}

Erysipelotrichaceae (E.ry.si.pe.lo.tri.cha'ce.ae. N.L. fem. n. Erysipelothrix type genus of the family; -aceae ending to denote a family; N.L. fem. pl. n. Erysipelotrichaceae the Erysipelothrix family).

The description is based on the generic description of Erysipelothrix (Jones, 1986; data obtained in this study). Straight or slightly curved, slender rods; some strains have a tendency to form long filaments. Non-motile. Endospores are not produced. Menaquinones are absent. Murein belongs to the B-cross-linking type, having L-alanine in position 3 of the peptide subunit and an interpeptide 
Table 1. Phenotypic properties that differentiate the novel isolate from Erysipelothrix strains, as determined by the API 32 STREPT and Biolog GP microplate panels

Taxa: 1, E. inopinata MF-EP02 ${ }^{\mathrm{T}}$; 2, E. rhusiopathiae DSM 5055 ${ }^{\mathrm{T}}$; 3, E. rhusiopathiae DSM 5056; 4, E. rhusiopathiae DSM 5057; 5, E. rhusiopathiae DSM 5058; 6, E. tonsillarum DSM $14972^{\mathrm{T}}$. According to API 32 STREPT, all strains were positive for glycyl tryptophan arylamidase, pyroglutamic acid arylamidase and acid production from glucose. All strains were negative for oxidase, aminopeptidase, hydrolysis of starch, gelatin, DNA and casein, urease, acid from mannitol, sorbitol, raffinose, sucrose, L-arabinose, D-arabitol, cyclodextrin, glycogen, pullulan, maltose, melibiose, melezitose and tagatose, $\beta$-glucuronidase, production of acetoin and hydrolysis of hippurate. As determined with Biolog GP, all strains use the following substrates: adenosine, uridine, methyl pyruvate, $N$-acetylglucosamine and $\alpha$-D-glucose. All strains are negative for methyl $\beta$-D-glucoside, D-tagatose, lactamide, alaninamide, D-arabitol, lactulose, methyl $\alpha$-D-mannoside, D-lactic acid methyl ester, D-alanine, $\beta$-cyclodextrin, maltose, palatinose, turanose, L-lactic acid, L-alanine, dextrin, maltotriose, xylitol, D-malic acid, L-asparagine, glycogen, D-mannitol, D-raffinose, L-malic acid, inulin, L-fucose, L-rhamnose, acetic acid, L-glutamic acid, adenosine 5'-monophosphate, mannan, D-melezitose, $\alpha$-hydroxybutyric acid, monomethyl succinate, glycyl-L-glutamic acid, thymidine $5^{\prime}$-monophosphate, Tween 40 , D-galacturonic acid, D-melibiose, $\beta$-hydroxybutyric acid, propionic acid, L-pyroglutamic acid, uridine $5^{\prime}$-monophosphate, Tween 60 , methyl $\alpha$-D-galactoside, sedoheptulosan, $\gamma$-hydroxybutyric acid, pyruvic acid, L-serine, fructose 6-phosphate, D-gluconic acid, methyl $\beta$-D-galactoside, D-sorbitol, $p$-hydroxyphenyl acetic acid, succinamic acid, putrescine, glucose 1-phosphate, stachyose, $\alpha$-ketoglutaric acid, succinic acid, 2,3-butanediol, glucose 6-phosphate, amygdalin, $m$-inositol, methyl $\alpha$-D-glucoside, sucrose, $\alpha$-ketovaleric acid, $N$-acetyl L-glutamic acid and DL- $\alpha$-glycerol phosphate. + , Positive; - , negative; $\mathrm{w}$, weak.

\begin{tabular}{|c|c|c|c|c|c|c|}
\hline Characteristic & 1 & 2 & 3 & 4 & 5 & 6 \\
\hline \multicolumn{7}{|l|}{ API STREPT: } \\
\hline$\beta$-Glucosidase & + & - & - & - & - & + \\
\hline Ribose (acid) & $\mathrm{W}$ & - & - & - & - & + \\
\hline Lactose (acid) & - & + & + & + & + & - \\
\hline Trehalose (acid) & + & - & - & - & - & - \\
\hline$N$-Acetyl- $\beta$-glucosaminidase & + & + & - & $\mathrm{w}$ & + & + \\
\hline$\beta$-Mannosidase & $\mathrm{W}$ & - & - & - & - & - \\
\hline \multicolumn{7}{|c|}{ Utilization of (Biolog GP Microplate panel): } \\
\hline L-Arabinose & - & + & + & + & + & $\mathrm{W}$ \\
\hline$N$-Acetyl-D-mannosamine & - & + & + & + & + & + \\
\hline Arbutin & + & - & - & - & - & - \\
\hline Cellobiose & + & - & - & - & - & - \\
\hline D-Fructose & - & + & + & + & + & + \\
\hline D-Galactose & - & + & + & + & + & + \\
\hline Gentiobiose & + & - & - & - & - & - \\
\hline$\alpha$-D-Lactose & - & + & + & + & + & - \\
\hline D-Mannose & - & + & + & $\mathrm{W}$ & + & - \\
\hline 3-Methyl glucose & - & - & - & - & + & - \\
\hline D-Psicose & - & + & + & + & + & + \\
\hline D-Ribose & $\mathrm{W}$ & - & + & + & + & + \\
\hline Salicin & + & - & - & - & - & - \\
\hline D-Trehalose & + & - & - & - & - & - \\
\hline Xylose & - & - & + & + & + & w \\
\hline Glycerol & + & - & - & - & - & - \\
\hline
\end{tabular}

bridge that consists of Gly $\rightarrow$ L-Lys $\rightarrow$ L-Lys. $\mathrm{C}_{16: 0}, \mathrm{C}_{18: 1} 9$ cis and $\mathrm{C}_{18: 0}$ are predominant fatty acids. Aerobic to facultatively anaerobic. Chemoorganotrophic; metabolism is respiratory and weakly fermentative. Acid, but no gas, is produced from glucose and other carbohydrates. DNA $\mathrm{G}+\mathrm{C}$ content is $36-40 \%$ (HPLC, $T_{\mathrm{m}}$, Bd). Some strains are pathogenic for mammals and birds. The 16S rRNA gene-directed primer pair (forward, 5'-TGATGCCATAGAAACTGGTA-3'; reverse, 5'-CTGTATCCGCCATAACTA-3') specifically amplifies the DNA of members of the genus Erysipelothrix. Belongs phylogenetically to the
Firmicutes. Type genus is Erysipelothrix (Migula 1900) Buchanan 1918, 55.

\section{Description of Erysipelothrix inopinata sp. nov.}

Erysipelothrix inopinata (in.o.pi.na'ta. L. fem. adj. inopinata unexpected).

Cells are Gram-positive, catalase- and oxidase-negative, non-motile, non-spore-forming rods, approximately $0.5 \mu \mathrm{m}$ in width and $1 \cdot 5-3 \cdot 0 \mu \mathrm{m}$ in length. Surface colonies on 
BHI (Difco) after 2 days incubation are punctiform to approximately $1.5 \mathrm{~mm}$ in diameter, creamy white, undulate, convex, translucent and soft. Growth occurs under aerobic and anaerobic conditions in BHI and columbia blood media, preferably at $\mathrm{pH} 8$. Growth occurs at 20 and $40{ }^{\circ} \mathrm{C}$, but not at $45^{\circ} \mathrm{C}$. The optimal temperature for growth is $25-30^{\circ} \mathrm{C}$. Physiological properties are indicated in Table 1 . DNA G $+\mathrm{C}$ content is $37 \cdot 5 \mathrm{~mol} \%$ (HPLC).

Type strain is MF-EP02 ${ }^{\mathrm{T}}\left(=\mathrm{DSM} 15511^{\mathrm{T}}=\mathrm{CIP} 107935^{\mathrm{T}}\right)$. Isolated from vegetative broth used for preparation of growth media.

\section{Acknowledgements}

We thank Ina Kramer and Jolantha Swiderski for their involvement in sequence and phylogenetic analyses, respectively. The skilful technical assistance of Bettina Sträubler (DNA base composition) and Anika Vester (RiboPrinting and chemotaxonomic analyses) is gratefully acknowledged.

\section{References}

Collins, M. D. \& Jones, D. (1981). Distribution of isoprenoid quinone structural types in bacteria and their taxonomic implication. Microbiol Rev 45, 316-354.

Collins, M. D., Pirouz, T., Goodfellow, M. \& Minnikin, D. E. (1977). Distribution of menaquinones in actinomycetes and corynebacteria. J Gen Microbiol 100, 221-230.

Collins, M. D., Lawson, P. A., Willems, A., Cordoba, J. J., FernandezGarayzabal, J., Garcia, P., Cai, J., Hippe, H. \& Farrow, J. A. E. (1994). The phylogeny of the genus Clostridium: proposal of five new genera and eleven new species combinations. Int J Syst Bacteriol 44, 812-826.

DeSoete, G. (1983). A least squares algorithm for fitting additive trees to proximity data. Psychometrika 48, 621-626.

Felsenstein, J. (1993). PHYLIP (phylogeny inference package), version 3.5c. Department of Genetics, University of Washington, Seattle, USA.

Groth, I., Schumann, P., Weiss, N., Martin, K. \& Rainey, F. A. (1996). Agrococcus jenensis gen. nov., sp. nov., a new genus of actinomycetes with diaminobutyric acid in the cell wall. Int J Syst Bacteriol 46, 234-239.

Jones, D. (1986). Genus Erysipelothrix. In Bergey's Manual of Systematic Bacteriology, pp. 1245-1249. Edited by P. H. A. Sneath, N. S. Mair, M. E. Sharpe \& J. G. Holt. Baltimore: Williams \& Wilkins.

Jukes, T. H. \& Cantor, C. R. (1969). Evolution of protein molecules. In Mammalian Protein Metabolism, pp. 21-132. Edited by H. N. Munro. New York: Academic Press.

Ludwig, W., Strunk, O., Westram, R. \& 29 other authors (2003). ARB, a software environment for sequence data (http://www2.mikro. biologie.tu-muenchen.de/arb/).

MacKenzie, S. L. (1987). Gas chromatographic analysis of amino acids as the $N$-heptafluorobutyryl isobutyl esters. J Assoc Off Anal Chem 70, 151-160.
Makino, S., Okada, Y., Maruyama, T., Ishikawa, K., Takahashi, T., Nakamura, M., Ezaki, T. \& Morita, H. (1994). Direct and rapid detection of Erysipelothrix rhusiopathiae DNA in animals by PCR. J Clin Microbiol 32, 1526-1531.

Mesbah, M., Premachandran, U. \& Whitman, W. B. (1989). Precise measurement of the $\mathrm{G}+\mathrm{C}$ content of deoxyribonucleic acid by high-performance liquid chromatography. Int J Syst Bacteriol 39, 159-167.

Migula, W. (1900). System der Bakterien, vol. 2. Jena: Gustav Fischer. Miller, L. T. (1982). Single derivatization method for routine analysis of bacterial whole-cell fatty acid methyl esters, including hydroxy acids. J Clin Microbiol 16, 584-586.

Rainey, F. A., Ward-Rainey, N., Kroppenstedt, R. M. \& Stackebrandt, E. (1996). The genus Nocardiopsis represents a phylogenetically coherent taxon and a distinct actinomycete lineage: proposal of Nocardiopsaceae fam. nov. Int J Syst Bacteriol 46, $1088-1092$.

Sasser, M. (1990). Identification of Bacteria by Gas Chromatography of Cellular Fatty Acids (technical note no. 101). Newark, DE: MIDI Inc. (http://www.midi-inc.com/media/pdfs/TechNote_101.pdf).

Schleifer, K. H. \& Kandler, O. (1972). Peptidoglycan types of bacterial cell walls and their taxonomic implications. Bacteriol Rev 36, 407-477.

Schubert, K. \& Fiedler, F. (2001). Structural investigations on the cell surface of Erysipelothrix rhusiopathiae. Syst Appl Microbiol 24, 26-30.

Skerman, V. B. D., McGowan, V. \& Sneath, P. H. A. (1980). Approved lists of bacterial names. Int J Syst Bacteriol 30, 225-420.

Smibert, R. M. \& Krieg, N. R. (1994). Phenotypic characterization. In Methods for General and Molecular Bacteriology, pp. 607-655. Edited by P. Gerhardt, R. G. E. Murray, W. A. Wood \& N. R. Krieg. Washington, DC: American Society for Microbiology.

Stackebrandt, E. \& Goebel, B. M. (1994). Taxonomic note: a place for DNA-DNA reassociation and 16S rRNA sequence analysis in the present species definition in bacteriology. Int J Syst Bacteriol 44, 846-849.

Takahashi, T., Fujisawa, T., Benno, Y., Tamura, Y., Sawada, T., Suzuki, S., Muramatsu, M. \& Mitsuoka, T. (1987). Erysipelothrix tonsillarum sp. nov. isolated from tonsils of apparently healthy pigs. Int J Syst Bacteriol 37, 166-168.

Takahashi, T., Fujisawa, T., Tamura, Y., Suzuki, S., Muramatsu, M., Sawada, T., Benno, Y. \& Mitsuoka, T. (1992). DNA relatedness among Erysipelothrix rhusiopathiae strains representing all twentythree serovars and Erysipelothrix tonsillarum. Int J Syst Bacteriol 42, 469-473.

Takeshi, K., Makino, S., Ikeda, T. \& 7 other authors (1999). Direct and rapid detection by PCR of Erysipelothrix sp. DNAs prepared from bacterial strains and animal tissues. J Clin Microbiol 37, 4093-4098.

Willems, A., Moore, W. E. C., Weiss, N. \& Collins, M. D. (1997). Phenotypic and phylogenetic characterization of some Eubacteriumlike isolates containing a novel type B wall murein from human feces: description of Holdemania filiformis gen. nov., sp. nov. Int J Syst Bacteriol 47, 1201-1204.

Wood, R. L. \& Shuman, R. D. (1975). Swine erysipelas. In Diseases of Swine, 4th edn, pp. 565-620. Edited by H. W. Dunne \& A. D. Leman. Ames, IA: State University Press. 